\title{
Quantitative Criteria for Adequacy of Academic Library Collections
}

The authors challenge accepted doctrine which asserts that the adequacy of an academic library cannot be measured by the number of books which it contains. Out of their feeling that the Standards for College Libraries and the Standards for Junior College Libraries are inadequate for estimating the sizes (in volumes) required for minimum adequacy by libraries of institutions of higher education of widely differing characteristics, they developed new formulas for this purpose. These formulas attempt to identify the principal factors affecting academic needs for books and to ascribe suitable weights to each factor. The authors then illustrate the application of the formulas to specific institutions, and conclude that while the results are useful, further research is needed. They end by suggesting specific topics for such research.

I AN THE ADEQUACY of the collection of an academic library be measured by the number of books which it contains? Respectable authorities say "No!"

"The adequacy of the college library's collections cannot be measured in quantitative terms," asserts a well-known textbook in the field of college library administration. "To judge a collection superior or inferior on the basis of the volume holdings," it maintains, "is as absurd as rating a college on the basis of its enrollment."

Regional accrediting agencies agree. "The actual number of books which a library contains is not a stable measure of the adequacy of the library." "More important than the total number of books in the stacks is the extent to which the selection of volumes accurately re-

${ }^{1}$ G. R. Lyle, The Administration of the College Library. Third ed. (New York: H. W. Wilson Co, 1961), p. 399.

Mr. Clapp is President and Mr. Jordan is on the staff of the Council on Library Resources, Inc., Washington, D.C. flects the needs of the institution as defined by its educational task." ${ }^{3}$ "It will be noted that no mention is made here of required minima for . . . library holdings. ... . The adequacy of each institution's resources must be judged in terms of its program." "Every [academic] library must . . . be evaluated in its own setting rather than by comparison with general patterns or norms, because each library must support a particular educational program."5 And similarly the Northwest Association, 1957, and the Western Association, 1963, while concerned for the "adequacy" of the academic library, provide no yardstick for

\footnotetext{
${ }^{2}$ North Central Association of Colleges and Secondary Schools Committee on Standards, College and University Accreditation Standards-1957 (Chieago: ACRL, 1958), p. 11.

a North Central Association of Colleges and Seconary Schools. Commission on Colleges and Universities, Guide for the Evaluation of Institutions of Higher Education, 1961, p. 16.

4 Middle States Association of Colleges and Secondary Schools. Commission on Institutions of Higher Education, Characteristics of Excellence in Higher Education and Standards for Middle States Accreditation, 1957 , D. 3 .

Morris A. Gelfand, "Techniques of Library Evaluators in the Middle States Association." College and Research Libraries, XIX (July 1958), 305-20.
} 
the measurement of that quality., ${ }^{6}$ The only regional association which makes an obeisance in the direction of a quantitative measure (but in a manner which approximates mockery) is the Southern Association: "The book and periodical collection should, by quality, size, and nature, support and stimulate the entire educational program .... the following should be used as a reference: Library Statistics of Colleges and Universities. Annual Analytic Report. ... In using this reference, institutional authorities should consider it a serious danger signal if the library regularly falls in the lowest quarter of any of the categories analyzed."8

When, as in these cases, standardizing authorities omit or refuse to set standards in quantitative terms, the budgeting and appropriating authorities, who cannot avoid quantitative bases for their decisions, are compelled to adopt measures which, though perhaps having the virtue of simplicity, may be essentially irrelevant. ${ }^{9}$

It is not surprising, in consequence, that the Standards for College Libraries adopted in 1959 by the Association of College and Research Libraries of the American Library Association, while properly placing primary emphasis upon quality and the means for achieving it, should also include sufficient numerical criteria to meet to a degree the need for quantitative standards.

Specifically, these Standards provide that fifty thousand "carefully chosen" volumes may serve as the minimum for the library of a college of up to six hun-

\footnotetext{
- Northwest Association of Secondary and Higher Schools, Guide for Self-Evaluation' and Accreditation of Higher Schools, 1957, p. 9.

7 Western Association of Schools and Colleges. Accrediting Commission for Senior Colleges and Universities, Statement of Standards, 1963, p. 2.

8 Southern Association of Colleges and Schools. College Delegate Assembly, Standards, 1962, p. 31.

For example, in California a formula for the annual book fund of the state colleges provided four books per student for the first one thousand students, two for the next four thousand, ete. A recommendation to change this formula proposed the provision of forty books per student by a certain date. But neither formula is directly related to the quality of the library. Program for the Development of California State College Libraries (n.p., August 1962). D. 2-3.
}

dred students (full-time equivalent); that "steady growth" is essential but may slacken when the collection reaches approximately three hundred thousand volumes; and that for each two hundred students above the initial six hundred there should be an additional ten thousand volumes. It is emphasized that these are minimal figures. ${ }^{10}$

The Standards for Junior College Libraries, likewise promulgated by the Association of College and Research Libraries, are similarly insistent upon quality, but similarly offer some quantitative assistance. They require that an institution of up to one thousand students (fulltime equivalent) should have a minimum of twenty thousand volumes exclusive of duplicates and textbooks and suggest that this figure should be increased by five thousand for each additional five hundred students beyond one thousand. Again, it is emphasized that these are minimal figures. ${ }^{11}$

In neither case, however, are the suggested quantitative criteria convincing in the sense that they rest on demonstrations of actual numbers of books required for specific educational purposes. Instead, the suggested figures admittedly reflect the accidentals of college library statistics (without indication of how this reflection is effected) or agreement among librarians consulted. The requirements for additional books are based in one case upon an apparent "correlation between the growth of the student body and the growth of the collection," and in the other simply upon "consultation with many junior college librarians." Finally, the Standards for College Libraries are by definition inapplicable to institutions stressing advanced research or granting degrees beyond the Master's, while the Standards for Junior College

\footnotetext{
10 [American Library Association. Association of College and Research Libraries], "Standards for College Libraries." College and Research Libraries, XX (July 1959), 274-80.

11 [American Library Association. Association of College and Research Libraries], "Standards for Junior College Libraries." College and Research Libraries, XXI (May 1960), 200-206.
} 
Libraries, although recognizing that institutions with a multiplicity of programs may need minimal collections of two or three times the basic figure of twenty thousand volumes, do not state at what point this requirement takes effect.

The present authors recently needed formulas for producing estimates of the size required for minimum adequacy by the library collections of a number of academic institutions of widely differing characteristics. It was important that these estimates should carry conviction to the planning, budgeting, and appropriating bodies concerned. Available standards were found unsuitable for producing the desired result. Accordingly, an attempt was made to develop formulas in which separate account would be taken of the principal factors that affect the requirements for books in connection with academic programs, and in which each factor would be weighted in a manner capable of being related to and justified by practice.

The results of this attempt, though admittedly but a beginning and needing much improvement, were found useful for the purpose for which they were designed ${ }^{12}$ and are consequently presented here as of possible wider interest. They invite exploration of the conditions which affect academic needs for books, of the relative weights which should be attached to the various controlling factors, and of the basic hypothesis itselfnamely, that it is possible to provide a meaningful quantitative measure of adequacy in library collections.

\section{Formulas for Estimating Size of ACAdemic Library Collections Required for Minimum Adequacy}

The minimum size required for the adequacy of an academic library differs from institution to institution depending

${ }^{2} \mathrm{~V}$. W. Clapp and R. T. Jordan, The Libraries of the State-Assisted Institutions of Higher Education in Ohio-Their Maintenance and DevelopmentGuidelines for Policy. Prepared for Academy for Educational Development, Inc. (Washington, D. C., 1964). upon the combined effect of the variables constituting the controlling factors in each case. Among the most important of these are:

- The student body-size, composition (graduate or undergraduate, full-time or part-time, resident or nonresident, etc.), scholastic aptitude, socio-economic and intellectual background.

- The faculty-size, involvement in research, "library-mindedness," etc.

- The curriculum-number of departments of instruction, number of courses, proportion of laboratory to literature courses, number of undergraduate "majors," number of fields of masters' and doctors' degrees, number of professional schools, etc.

- Methods of instruction-extent and use of textbooks, reading assigned and independent study, honors work, etc.

- Availability of suitabłe places for study on the campus.

- Geography of the campus-proximity to metropolitan areas, to other large libraries, etc.

- The intellectual climate-inducements and distractions to study, etc.

It is obvious that these factors differ widely in their susceptibility to measurement. Only those that can be most easily and meaningfully measured were given places in the following tables which constitute the formulas.

\section{NOTES ON TABLE 1}

The formula presumes that even liminal or minimum adequacy can be achieved with its assistance only if all material is carefully chosen with a view to the purpose to be served, and the weeding program is as active and realistic in relation to needs as is the program of acquisition.

Averages. Because of wide disparities in the extent of the literatures of various subjects, the figures suggested by the table must be considered as averages of the literatures of subjects of academic 
TABLE 1

Formula for Estrmating the Size for Liminal Adequacy of the Collections of Sentor College and University Libraries

\begin{tabular}{|c|c|c|c|c|c|c|}
\hline \multirow[b]{2}{*}{ (1) } & \multicolumn{2}{|c|}{ Bоoкs } & \multicolumn{2}{|c|}{ Pertodicals } & \multirow{2}{*}{$\begin{array}{c}\begin{array}{c}\text { Docu- } \\
\text { MENTS }\end{array} \\
\begin{array}{c}\text { Volumes } \\
(6)\end{array}\end{array}$} & \multirow{2}{*}{$\begin{array}{c}\text { TotAL } \\
\begin{array}{c}\text { Volumes } \\
(7)\end{array}\end{array}$} \\
\hline & $\begin{array}{l}\text { Titles } \\
\text { (2) }\end{array}$ & $\begin{array}{l}\text { Volumes } \\
\text { (3) }\end{array}$ & $\begin{array}{c}\text { Titles } \\
\text { (4) }\end{array}$ & $\begin{array}{c}\text { Volumes } \\
\text { (5) }\end{array}$ & & \\
\hline $\begin{array}{l}\text { To a basic collection, viz.: } \\
\text { 1. Undergraduate library } \\
\text { Add for each of the following as in- } \\
\text { dicated: } \\
\text { 2. Faculty member (full time } \\
\text { equivalent) } \\
\text { 3. Student (graduate or under- } \\
\text { graduate in full time equiv- } \\
\text { alents) } \\
\text { 4. Undergraduate in honors or } \\
\text { independent study pro- } \\
\text { grams andergraduate con- } \\
\text { 5. Field of undergajor" subject } \\
\text { centration- "major } \\
\text { field } \\
\text { 6. Field of graduate concentra- } \\
\text { tion-Master's work or } \\
\text { equivalent } \\
\text { 7. Field of graduate concentra- } \\
\text { tion-Doctoral work or } \\
\text { equivalent }\end{array}$ & 2,000 & 2,400 & 250 & 3,750 & 5,000 & 50,750 \\
\hline
\end{tabular}

interest. It is not too difficult to estimate the size of a collection for work at a given level in a single subject; it is when the library is required to serve the interest of many users at many levels in many subjects, as in an institution of higher education, that estimates of size become difficult.

Interdependence of factors. No factor represented in the formula will be operative in isolation; each is dependent on others. For example, it is not suggested that 240 monograph volumes are sufficient for an undergraduate field of concentration (line 5). Obviously, there will be contributions to each field of concentration resulting from each of the other variables (lines 1 through 4 ).

Microcopy. The table presumes that most of the materials estimated in lines 1-4 will be in full-scale format. Even here, however, some of the less-frequently-used material (such as back files of newspapers) may be in microcopy. With respect to much of the little-used research material to be added in accord- ance with the estimates contained in lines 5-7, "adequacy" can be achieved with almost as much efficiency through the use of microcopy as with full-scale material. The table assumes that fully cataloged material in microform will be measured in volumes as though it were in original form.

Title-volume ratios. The title-volume ratio employed for books (columns 2 and 3 ) is $1: 1.2$ which falls between that (1:1.37) found to obtain in the National Union Catalog 13 and that (1:1.15) which is found in the Lamont library catalog. ${ }^{14}$ The ratio used for periodicals (columns 4 and 5) has been set at 1:15 (cf. the note on line 1, column 4). For documents (column 6) a title-volume ratio does not seem to be meaningful. In consequence, the total sizes of collections obtained by using the table are expressed only in volumes.

II E. E. Williams, "Magnitude of the Paper-Deterioration Problem as Measured by a National Union Catalog Sample," College and Research Libraries, XXIII (November 1962), 499, 543.

14 Catalogue of the Lamont Library, Harvard College (Harvard University Press, 1953). 
Line 1, Column 2. The figure of 50,750 volumes suggested as capable of providing threshold adequacy for an undergraduate collection derives authority from experience in the actual construction of lists for this purpose. The most important of these lists have been:

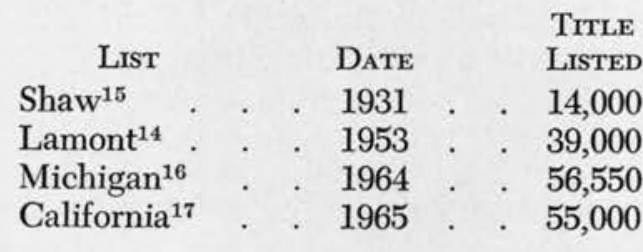

The Shaw list was a pioneering effort which set the pattern and the standard of excellence. The Lamont list was the first to be related to an actual undergraduate library, but it had many faults. The Michigan list learned from these. The California list (under construction at the library of the University of California at San Diego) has not only benefited from previous experience but has been executed under auspicious circumstances. The Library Council of the University of California recommended that the three new campuses currently being planned each have seventy-five thousandvolume libraries at opening day, since the experience of the growing campuses, Irvine in particular, suggests that it is difficult to give adequate service with a smaller collection. The California list, in consequence, provides for about sixty thousand volumes of monographs and fifteen thousand volumes of serials.

Line 1, Column 4. The figure of 250 periodical titles is supported by the Michigan list which includes 245 such titles and the California list which provides for fifteen thousand serial volumes representing nine hundred titles, of which the three hundred most useful are in runs of twenty or more years. Further-

${ }^{15}$ C. B. Shaw, A List of Books for College Libraries (American Library Association, 1981).

16 University of Michigan. Undergraduate Library, Shelf List. Rev. ed. (Ann Arbor, Michigan: University Mierofilms, Inc., 1964).

it [University of California at San Diego. Library, List of books selected for the libraries of three new campuses of the University of California.] In preparation for the press. more, the figure of two hundred and fifty is 50 per cent of the number of titles covered by the following standard periodical indexes published by the $\mathrm{H}$. W. Wilson Company, without which no (general) American library can expect to render adequate service:

\section{Readers' Guide to Periodical Litera-} ture (selected general and nontechnical periodicals)

International Index (social sciences and humanities)

Applied Science and Technology Index

\section{Total}

Line 1, Column 6. The figure of five thousand documents would admit the most important publications of the U.S. Congress, the Bureau of the Census and other federal executive agencies, the United Nations and its specialized agencies, states of the United States, etc.

Line 2. If the library which provides merely threshold adequacy for undergraduates is to permit the members of the teaching staff to keep up in their subjects even liminally, the collection must be enriched for their benefit. An enrichment amounting to fifty titles (e.g., three per year for sixteen years), one periodical subscription and twentyfive documents per faculty member would seem to be a minimum. ${ }^{18}$

resented by line 1 takes no account what Line 3. The undergraduate library rep-2 दsoever of the size of the student body. As this increases, the number of copies (not titles) will have to be increased. At the suggested rate of twelve volumes per student, every book in the undergraduate library could be duplicated by the time that the student body had risen to 4,230 . In other words, there could then be, if desired, two identical undergrad-

\footnotetext{
18 The observed tendency for stable and continuing academic libraries to double in size every sixteen years that is associated with the name of Fremont Rider suggests that sixteen years represents a period at which the collections of such libraries require a substantial degree of renewal. Accordingly, this period is here adopted for the cycle of renewal for the additional materials purchased for faculty, etc.
} 
uate collections, each serving 2,115 students. It is more likely, of course, that all 4,230 would use the same library but that the books more in demand would be supplied in multiple copies.

Line 4. The typical student in an honors or independent study program may read or use hundreds of books each year. However, since the criterion sought here is merely threshold adequacy, a very low figure is used.

Line 5. The undergraduate collection (line 1) will rarely have as many as several hundred titles in each field in which an undergraduate "major" is offered. By contrast, "basic lists" for such subjects typically include two thousand and more titles (see note on line 6, below). Accordingly, the reinforcement suggested here, amounting to only 17 per cent of this quantity, is very modest.

Line 6. At the point at which graduate work is offered leading to the master's degree or its equivalent, the collection must assume some of the characteristics of $\cdot$ a research collection, albeit at the lowest level. The quantity of material for addition here is suggested by the numerous "basic lists" which typically include two thousand and more titles, e.g.:

Anthropology 19

Area studies (Asia, Africa, Eastern

Europe, Latin America) ${ }^{20}$

Art reference books ${ }^{21}$

China modern-economic and social development ${ }^{22}$

Communism-books in English only ${ }^{23}$

19 D. G. Mandelbaum and others, eds., Resources for the Teaching of Anthropology; Including a Basic List of Books and Periodicals for College Libraries Compiled by Rexford S. Beckham with the Assistance of Marie P. Beckham (University of California, 1963). 2,000 titles.

${ }^{20}$ American Universities Field Staff, A Select Bibliography: Asia, Africa, Eastern Europe, Latin Amerioa. (AUFS, 1960) : Supplements, 1961, 1963, 6,000 titles in basic list, 500 in each of the supplements.

${ }^{21}$ M. W. Chamberlain, Guide to Art Reference Books (Chicago: American Library Association, 1959). 2,500 titles, 250 journals, 100 series.

${ }_{22}$ T,-L. Yuan: Economic and Social Development of Modern China: a bibliographical guide (New Haven: Human Relations Area Files, 1956). Over 2,000 titles.

29 W. Kolarz, Books on Communism; a Bibliography, 2d ed. London: Allen \& Unwin, 1964). Approximately 2,500 titles, restricted to English.
Electronics ${ }^{24}$

Physics 25

United States of America-life and thought ${ }^{26}$

Line 7. These 24,500 volumes represent but a fraction of the literature of any but the most recently-developed subject, and can ordinarily be expected to present a subject only in its most recent aspects, neglecting historical development. Yet as recently as 1955 one of the most literature-based of the learned professions adopted twenty thousand volumes as a passing grade for its training centers in the United States, ${ }^{27}$ and even in 1964 sixteen of these centers still had fewer than thirty thousand volumes. It is also true that the literatures of several disciplines support each other, as chemistry, biochemistry, physiology, anatomy, neurology, psychology, and other related sciences contribute to make a medical library.

\section{Notes ON TABLE 2}

As with Table 1 it is presumed that all material will be carefully selectedand weeded-with reference to the purpose to be served.

As with Table 1, also, the formula provides only for a minimum. When it is seen, e.g. in the notes on lines 2 and 4, out of what this minimum is constructed, few institutions should be willing to stay there.

Averages. Similarly as for Table 1, the figures sugested here must be construed as averages. Obviously, courses in court stenography or in conversational Spanish do not require the same library support as courses in theatre or decorative arts.

Government publications. No special

2 C. K. Moore, Electronics; a Bibliographic Guide (Macmillan, 1961). Over 2,000 titles in 68 subject areas.

${ }^{25}$ American Institute of Physics, Check List of Books for an Undergraduate Physics Library (New York: AIP, 1962). 1,883 titles.

26 U. S. Library of Congress, General Reference and Bibliography Division: A Guide to the Study of the United States of America (Washington: U. S. Government Printing Office, 1960). 6,500 titles.

${ }^{27}$ Association of American Law Schools, Proceedings, 1955 , p. 325 . 
TABLE 2

Formula for Estimating the Stze for Liminal Adequacy of Junior or COMMUNITy COLlege Libraries

(1)

\begin{tabular}{|c|c|c|c|c|c|}
\hline \multirow{2}{*}{ (1) } & \multicolumn{2}{|c|}{ Воoкs } & \multicolumn{2}{|c|}{ Periodicals } & \multirow{2}{*}{$\begin{array}{c}\text { Total } \\
\begin{array}{c}\text { Volumes } \\
(6)\end{array}\end{array}$} \\
\hline & $\begin{array}{c}\text { Titles } \\
\text { (2) }\end{array}$ & $\begin{array}{l}\text { Volumes } \\
\text { (3) }\end{array}$ & $\begin{array}{c}\text { Titles } \\
(4)\end{array}$ & $\begin{array}{c}\text { Volumes } \\
(5)\end{array}$ & \\
\hline $\begin{array}{l}\text { To a basic collection, viz.: } \\
\text { 1. A collection to support a two-year gen- } \\
\text { eral education or liberal arts (transfer } \\
\text { or university parallel) program. } \\
\text { Add for each of the following as indicated: }\end{array}$ & 12,500 & 15,000 & 125 & 1,875 & 16,875 \\
\hline $\begin{array}{l}\text { 2. Faculty member (full time equivalent) } \\
\text { 4. Student (full time equivalent) } \\
\text { terminal, in which courses are offered } \\
\text { beyond the standard general education } \\
\text { or liberal arts transfer program }\end{array}$ & $\begin{array}{r}30 \\
\ldots\end{array}$ & $\begin{array}{r}36 \\
4\end{array}$ & 1 & $\begin{array}{r}15 \\
1\end{array}$ & $5 \frac{1}{5}$ \\
\hline
\end{tabular}

provision has been made for these; to the extent included, they would be considered as books or periodicals.

Title-volume ratios. Same as for Table 1.

Line 1, Column 2. Similarly as for the senior colleges, there have been attempts to prepare basic selections of books for junior college libraries, of which the more important are as follows:

\begin{tabular}{|c|c|c|}
\hline List & DAtE & TItLes Listed \\
\hline Mohrhardt ${ }^{28}$ & 1937 & 5,300 \\
\hline Bertalan ${ }^{29}$. & 1954 & 4,000 \\
\hline Trinkner ${ }^{30}$ & 1963 & 20,000 \\
\hline
\end{tabular}

The earlier of these are out of date, and none is now authoritative. It is consequently not possible to give to the initial step in the formula of Table 2 even the degree of empirical support which is available for Table 1. The development of such support would be an important step toward the improvement of the standards for junior college libraries.

Line 1, Column 4. The number of periodicals is arbitrarily set at one half the number for the four-year colleges.

Line 2 . This provision amounts to few-

${ }^{28}$ F. E. Mohrhardt, A List of Books for Junior College Libraries (Chicago: American Library Association, 1987).

${ }^{\circ}$ F. J. Bertalan, Books for Junior Colleges (Chicago: American Library Association, 1954).

${ }^{30}$ C. L. Trinkner, Basic Books for Junior Colleges (Northport, Alabama: Colonial Press, 1963). er than two books per faculty member per year (if spread over sixteen years) plus one periodical. ${ }^{18}$

Line 3. This item provides for additional copies (not titles) required by the size of the student body. At the rate suggested the basic collection could be duplicated by the time there were 3,375 students. This figure obviously needs testing in practice.

Line 4. This item provides for each additional subject at the rate of six titles per annum with replacement over a sixteen-year period. ${ }^{18}$ In this connection, it may be noted that for the diversified program of the community college as contrasted with the narrower one of the junior college, the recent Rutgers Guide has the following to say:

The community college library should probably be larger than that of a comparable-sized four-year liberal arts college ... . because a greater amount of materials is needed to maintain the diversified programs offered by a comprehensive community college. ${ }^{31}$

\section{EXAMPLES OF ApPlication OF THE FORMULAS}

In Tables 3-5 the formulas of Tables 1-2 have been applied, by way of il-

${ }^{31}$ F. P. Merlo and W. D. Walling, Guide for Planning Community College Facilities (New Brunswick, N. J.: Division of Field Studies and Research, Graduate School of Education, Rutgers-The State University, 1964), p. 34 . 
lustration, to the data for a number of academic libraries. Because of the untested status of the formulas, the names of the institutions have been withheld unless there seemed to have been no risk of an unjustified pejorative judgment.

In Table 3 it is possible to compare, for four senior college libraries, the calculations resulting from the formula of Table 1 with those for additional volumes suggested by the Standards for College Libraries (viz., increments of ten thousand volumes, additional to the basic collection of fifty thousand, for each two hundred students beyond an original six hundred). It may be noted that the Standards are easier on the stronger institutions and harder on the weaker than is the formula of Table 1 .

In Table 4 are found certain libraries with enormous collections which are nevertheless found short of minimum adequacy by the formula of Table 1. Can this be possible?

The source of adverse judgment is found principally in column 7 (number of doctoral fields). Thus, library no. 139 with 1.67 million volumes, offers the doctor's degree in sixty-two fields as contrasted with Illinois' sixty fields supported by 3.6 million volumes. The interpretation to be put on the table, therefore, is not that the collections rated minus are in an absolute sense "inadequate," but that they are inadequate in relation to the programs which they are attempting to support-in other words that the institutions have overextended themselves in relation to the available library resources.
The libraries represented in Table 5 without exception possess collections exceeding the basic minimum size required by the Standards for Junior College Libraries, and in some cases their collections are several times this basic minimum. In spite of this all but two fail to meet the threshold of adequacy prescribed by the formula of Table 2 .

In Table 5 it is possible to compare the findings of the formula of Table 2 with those of the Standards for Junior College Libraries (viz., increments of five thousand volumes, added to the basic twenty thousand, for each five hundred students beyond the original one thousand). Two more institutions in the list are found adequate by the second than by the first criterion.

Source of data, Tables 3-5: Various, see footnotes. ${ }^{32-38}$ All data are for $1962 / 3$ or $1963 / 4$, extrapolated for some items for some institutions from prior years. Student and faculty figures have been reduced, in some cases arbitrarily, to full-time equivalents.

Column 1: Senior colleges; no. 4: A statesupported senior college.

Column 2: Faculty (full-time equivalent).

Column 3: Students (full-time equivalent).

Column 4: Honors students (postulated at 25 per cent of student body for nos. 1-3 and 10 per cent for no. 4 ).

Column 5: Fields of undergraduate concentration-"major" subject fields.

32 U. S. Office of Edueation, Library Statistics of Colleges and Universities, 1962-63. Institutional Data (Washington: U. S. Government Printing Office, 1964). Supplement (Chicago: American Library Association, [1964]).

* American Colleges and Universities. 9th ed. (Washington: American Council on Education, [1964]).

${ }^{34}$ American Junior Colleges, 6th ed. (Washington: American Council on Education, 1963).

as Junior College Directory (Washington: American Association of Junior Colleges, 1964).

se The World of Learning, 1963-64 (London: Europa Publications, 1964).

TABLE 3.

Application of Formula of Table 1 to Selected Senior Colleges

\begin{tabular}{|c|c|c|c|c|c|c|c|c|c|c|}
\hline (1) & (2) & (3) & (4) & (5) & (6) & (8) & (9) & (10) & (11) & (12) \\
\hline $\begin{array}{l}\text { 1. Oberlin . } \\
\text { 2. Swarthmore } \\
\text { 3. Antioch } \\
\text { 4. . . . }\end{array}$ & $\begin{array}{r}215 \\
110 \\
100 \\
90\end{array}$ & $\begin{array}{r}2,370 \\
975 \\
1,725 \\
2,200\end{array}$ & $\begin{array}{l}600 \\
250 \\
430 \\
220\end{array}$ & $\begin{array}{l}25 \\
20 \\
20 \\
25\end{array}$ & $\begin{array}{r}10 \\
10 \\
1 \\
2\end{array}$ & $\begin{array}{r}147,000 \\
114,000 \\
96,300 \\
103,000\end{array}$ & $\begin{array}{r}900,000 \\
245,000 \\
129,000 \\
65,000\end{array}$ & $\begin{array}{r}+512 \\
+115 \\
+34 \\
-37\end{array}$ & $\begin{array}{r}138,500 \\
68,750 \\
106,250 \\
130,000\end{array}$ & $\begin{array}{r}+550 \\
+256 \\
+21 \\
-50\end{array}$ \\
\hline
\end{tabular}


TABLE 4.

Application of Formula of Table 1 to Selected State-Supported oR State-Assisted UnIVERSTTIES

\begin{tabular}{|c|c|c|c|c|c|c|c|c|c|}
\hline (1) & (2) & (3) & (4) & (5) & (6) & (7) & (8) & (9) & (10) \\
\hline 1. Illinois & 150 & 30,275 & 3,025 & 200 & 125 & 60 & $2,683,000$ & $3,635,000$ & +35 \\
\hline 2. Michigan & 1,8 & & & 130 & 90 & 66 & 00 & $3,250,000$ & +32 \\
\hline 3. UCLA & 1,50 & 8,000 & 1,800 & 80 & 7 & 39 & $1,634,000$ & $2,000,000$ & +22 \\
\hline & 900 & 10,000 & 1,000 & 70 & 50 & 33 & $1,257,000$ & $1,350,000$ & +7 \\
\hline 5. & 375 & 9,600 & 960 & 90 & 60 & 2 & 477,000 & 412,000 & -14 \\
\hline 6. & 240 & & 47 & 3 & 16 & 2 & 246 , & 195,000 & -21 \\
\hline 7. & 900 & 14,400 & 1,440 & 70 & 45 & 29 & 1,202, & 865 , & -28 \\
\hline & 300 & 9,300 & 930 & 60 & 30 & 1 & 340,000 & 236,000 & -31 \\
\hline 9. & 2,200 & 30,66 & 3,06 & 165 & 100 & 62 & $2,555,000$ & $1,670,000$ & -35 \\
\hline 10. & 470 & 11,400 & 1,140 & 85 & 55 & 5 & 567,000 & 360,000 & -37 \\
\hline 11. & 300 & 5,360 & 540 & 50 & 30 & 3 & & & -30 \\
\hline 12. & 500 & 13,300 & 1,330 & 100 & 55 & 5 & 600,000 & 268,000 & -55 \\
\hline
\end{tabular}

Column 6: Fields of graduate concentration -master's work or equivalent.

Column 8: Size (volumes) of collection calculated by the formula of Table 1 .

Column 9: Size (volumes) of actual collection.

Column 10: Difference between columns 8 and 9 expressed as a percentage of column 8 . Plus indicates that the actual collection is larger than required by the formula; minus that it is smaller.

Column 11: Size (volumes) of collection calculated by the formula suggested by Standards for College Libraries.

Column 12: Difference between columns 9 and 11 expressed as a percentage of column 11. Plus indicates that the actual collection is larger than required by the formula; minus that it is smaller.

Source of data: See Table 3.

Column 1: State-supported or state-assisted universities.

Columns 2-6: Same as for Table 3.

Column 7: Fields of graduate concentration -doctoral work or equivalent.

Columns 8-10: Same as for Table 3.

Source of data: See Table 3.

Column 1: Junior or community colleges; nos. 3-7, junior or community colleges in California, Michigan and New York.

Column 2: Faculty (full time equivalent).

Column 3: Students (full time equivalent).

Column 4: Subject fields of study beyond standard general education or liberal arts transfer pattern.

Column 5: Size (volumes) of minimum collection calculated by formula of Table 2 .

Column 6: Size (volumes) of actual collection.

Column 7: Difference between columns 5 and 6 as a percentage of column 5 . Plus indicates that the actual collection is larger than required by the formula; minus that it is smaller.

Column 8: Size (volumes) of collection calculated by formula of Standards for Junior College Libraries.

Column 9: Difference between columns 6 and 8 as a percentage of column 8 . Plus indicates that collection is larger than required by the Standards; minus that it is smaller.

\section{Conclusion}

The adequacy of an academic library collection may be difficult to determine,

TABLE 5.

Application of Formula of Table 2 to Selected Junior or Communtty Colleges

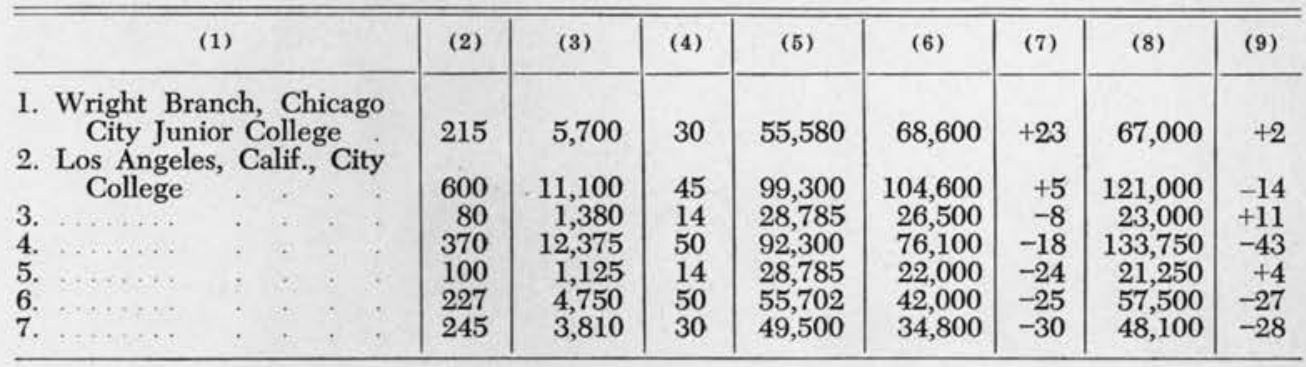


but there is no mystery about it. The difficulty arises simply from the quantity of detail and number of variables involved, far beyond the capability of any. visiting committee to assess merely on the basis of easy observation or sampling.

Yet every scholar has a notion of what in his own field constitutes adequacy for various purposes-undergraduate instruction, graduate teaching, advanced research, etc. This notion can in every case be expressed in concrete terms, i.e., in terms of a list of specific books. The contents of the list can in turn be made the subject of agreement or consensus of a number of scholars in a field. And the adequacy of an entire library is made up of the adequacies of its parts.

The best yardsticks of adequacy are therefore those to which we have become accustomed-the book-selection list and the specialized subject bibliography, frequently reviewed and brought up to date by experts and in the light of use. But to apply these yardsticks is, at the present time, something else again: manual checking and searching procedures are involved-slow, tiresome and costly.

Yet it may be foreseen that, with the advent of electronic catalogs the checking of a book-selection list or bibliography will become the mere routine of a mechanical process. Not.only will evaluation of collections be simplified thereby, but collection-building procedures will be assisted. The end result will be gains in the quality of collections.

The formulas described in this article have been developed in an attempt to find a method for estimating the size for minimal adequacy of academic library collections more convincingly than can be done with existing criteria. It may be validly objected that little more has been accomplished than to transfer the locus of conviction from an unknown whole to the unknown parts, of which the whole is composed. This may be readily admitted while calling attention to the fact that to break an estimate down into components is standard practice for convincing budgeting and appropriating bodies.

In any case, the attempt to identify and weigh the factors which affect the need for books in academic situations reveals gaps in our knowledge, to the filling of which research might profitably be directed. Among the questions requiring answers are:

- What are the tests of adequacy of an academic library collection?

- What is learned from experience regarding the contents of an undergraduate collection of minimum adequacy?

- How are these contents affected by variable factors such as geography, curriculum, teaching methods, intellectual climate, etc.?

- What constitutes adequacy for particular kinds of material at various levels of use-e.g., periodicals, government documents?

- What constitutes adequacy for the needs of faculty, honors students, etc.?

- What correlation, if any, exists between size of student body and size of collection?

- Is there a renewal or replacement cycle? What are its characteristics? Does it affect acquisition, weeding, or the estimates of cost of collection-building?

- What constitute adequate resources for graduate work and research in various subjects and at various levels? ${ }^{37}$

- Questions similar to the foregoing may be asked with respect to the collections of junior and community colleges.

\footnotetext{
a7 R. B. Downs, "Development of Research Collections in University Libraries," University of Tennessee Library Lectures, No. 4 (Knoxville: University of Tennessee, 1954), p. 1-15. Distinguishes four stages in the progress of a collection-the general information collection, the well-rounded reference collection, the fundamental research collection, and the comprehensive and specialized research collection.
} 